
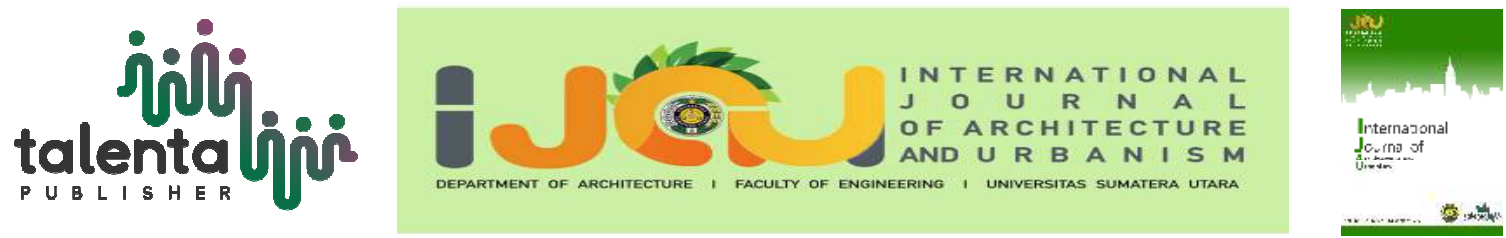

\title{
Evaluation of The Implementation of the Revitalization Program in Preservation of Van Den Bosch Fortress in Ngawi
}

\author{
Bayu Hermawan ${ }^{1 *}$, Arif Budi Sholihah ${ }^{1}$, Putu Ayu Pramanasari \\ Agustiananda ${ }^{1}$
}

Department of Architecture, Faculty of Civil Engineering and Planning, Universitas Islam Indonesia, Sleman, Yogyakarta, Indonesia

\begin{abstract}
One of the relics of Dutch colonial buildings in Indonesia is the Van Den Bosch Fortress, this fortress has a revitalization program that is in line with the heritage city program of the Direktorat Jendral Penataan Ruang Pekerjaan Umum dan Perumahan Rakyat Republik Indonesia (PUPR). The purpose of this study is to evaluate the extent of the implementation of revitalization to increase the benefits and direction of preservation of the fortress, and to support Ngawi Regency as a conservation activity for the Cultural Heritage City as the main strategy for urban development. Revitalization evaluation techniques are seen based on the level of vitality of the built area which includes several aspects such as decreasing physical quality of buildings, regional images, economic and activity social. The writer used the descriptive qualitative method by collecting data related to Fort Van den Bosch, then data analyzed by using the Miles and Huberman method. The results of the evaluation study found the implementation of the Van Den Bosch Fortification revitalization program encountered several obstacles and the revitalization program was divided into 2 , such as the core of building of the fort and the development of the fort area environment.
\end{abstract}

Keyword: van den bosch fortress, evaluation, conservation, revitalization

\section{Introduction}

The Netherlands has several relics in the form of buildings and structural systems when colonizing the Indonesian people. One of the relics of the Dutch colonial building is the fortress of Pendem, the real name of this fortress is "Benteng Van Den Bosch" while the name Pendem is the naming of the surrounding community. It is called the Pendem fort because it is located in the middle of the area which at that time was deliberately made lower than the surrounding land surface and surrounded by high land embankments, so that when viewed the fort was like a

*Corresponding author at:Jalan Kaliurang Km.14,5, Besi, Sleman, Krawitan, Umbulmartani, Ngemplak,

Kabupaten Sleman, Daerah Istimewa Yogyakarta 55584

E-mail address: hermawanbayu995@gmail.com 
hidden, but the embankments are now has decreased in height due to continuous erosion of rainwater

In the Ngawi District Regulation No. 10 of 2013 concerning preservation, development of cultural heritage and traditional cultural arts, states the preservation of the development of cultural heritage and traditional cultural arts as referred to in paragraph 1 is carried out through protection, development, and utilization. The architectural aspect as referred to in paragraph 1 letter $\mathrm{c}$ is one of the efforts to preserve Van Den Bosch Fortress [1].

Based on discussions with Mr. Chawari [2] as the head of the colonial section research team that handled the research at Benten Van Den Bosch at the Yogyakarta Archaeological Office, recently the Fort Van Den Bosch underwent a revitalization process. This revitalization activity is carried out by the Public Works Agency of Ngawi Regency and planned in 3 stages. The revitalization phase in Benteng Van Den Bosch includes: the first stage, revitalization of the core area of Benteng Van Den Bosch, the second stage is an activity which includes the development of the fort area, the last stage is to continue the development of the fort area environment [3][4].

The revitalization that is being carried out in the Benteng Van Den Bosch area is currently in line with the program implemented by Pusaka city from Direktorat Jendral Penataan Ruang (PUPR), which has also been allocated for the management of Lawang Sewu in Semarang. The government's program to revitalize the colonial area and the remaining old buildings so far still has several obstacles which include: ownership, planning, documentation and operational systems [5].

The purpose of this study is to evaluate the implementation of the revitalization program in the preservation of Fort Van Den Bosch to increase the value of benefits and direction in the preservation of the fort, and to support Ngawi Regency as a Heritage City. In line with the PUPR directorate general's spatial planning program which places the application of heritage management and preservation activities as the main strategy for urban development [6].

\section{Revitalization Theory}

The relationship of revitalization with preservation, basically revitalization is part of the conservation (preservation) method of buildings and historic areas [7]. In the Burra Charter [8], revitalization or adaptation is an effort that aims to revive and revive social, economic and environmental activities in buildings and historic areas that begin to lose the vitality of their original functions, by entering new functions according to the needs of the present. But with a note in the application of new functions must maintain the historical values contained so as not to eliminate the memory of history in the past. Danisworo [9], said revitalization is a very 
complex activity that includes several stages and requires a certain period of time, the stages in revitalization are as follows:

Physical Intervention

The image of the area is very closely related to the visual conditions of the area that serves to attract visitors. From here physical intervention is very necessary, physical intervention can be started in stages which includes physical improvement of buildings, connecting systems, and green open spaces.

Economic Rehabilitation

The physical development and improvement of the historical area are expected to be able to overcome the problems of the formal and informal economy so that it can enhance the added value of the historic area. It is necessary to develop mixed functions in revitalization which can lead to economic and social activities.

\section{Social Revitalization}

The success of revitalizing the historic area can be measured if it can create an attractive environment and have a positive impact on the social activities of the surrounding community.

\section{Research Methods}

The method used in this study is to use qualitative methods descriptively. Data collection techniques in this study are divided into two, namely data obtained from direct sources (primary data) and data from indirect sources (secondary data). Primary data includes:

1. Observations were made to observe and obtain data on the implementation of the revitalization program in the Van Den Bosch fort area which included the physical quality of the building, the image of the community and the economy.

2. Interviews were conducted with several people related to the fortress of Van Den Bosch which aims to find out what activities have been carried out in the revitalization of the Van Den Bosch Fort area.

3. Documentation is used to document the activities that have been carried out in the Van Den Bosch fort area.

While secondary data is obtained by collecting literature studies related to the fortress of Van Den Bosch, such as Journal, thesis, report data, and relevant internet sites.

\section{Data Analysis}

Data obtained regarding the fortress of Van Den Bosch will be processed using the analysis methods of Miles and Huberman, this analysis is carried out periodically and continues to 
produce complete data. Miles and Huberman [10] explained, the steps in analyzing using this method and divided into 3 types, which include:

Data reduction

The data that has been obtained about Benteng Van Den Bosch is summarized and the things that are considered to be basic are selected and then focused on the main points. Thus the data that has been reduced will provide a clear picture and facilitate the author in collecting data.

\section{Data Display}

After the data has been reduced, the next step is to present the data. In qualitative methods, data will be presented in several forms such as brief descriptions, charts, tables, and the like. presenting this data serves to simplify and understand what is happening and can plan further work based on what has been understood.

\section{Conclusion}

The final step in this method is to draw conclusions. The initial conclusions will be stated are still temporary and will change if there is no evidence that supports the data collection stage and if at the initial stage it is supported by valid and consistent evidence when the writer returns to the field to collect data, the conclusions found are a credible conclusion.

\section{Results and Discussion}

Building architecture of the Fort Van Den Bosch is a Dutch cultural heritage and can be seen from its European-like appearance, since its founding in 1839-1845, the fort building has never experienced significant changes, both in addition and subtraction. so that the architecture and building materials were still original, but the physical structure of the building was reduced or damaged, the roof of the fort had disappeared and other things began to break down, lifting bridges that were no longer visible, drainage and trenches were no longer functioning (Figure 1$3)$.

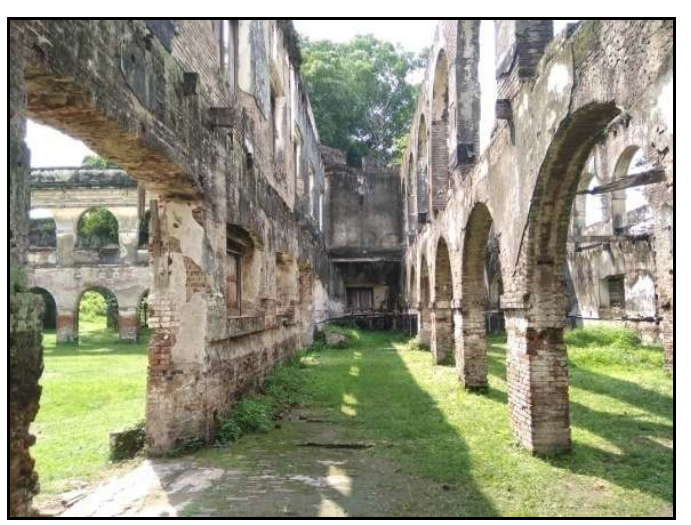

Figure 1. The roof of the fort that was lost and the floor covered by grass

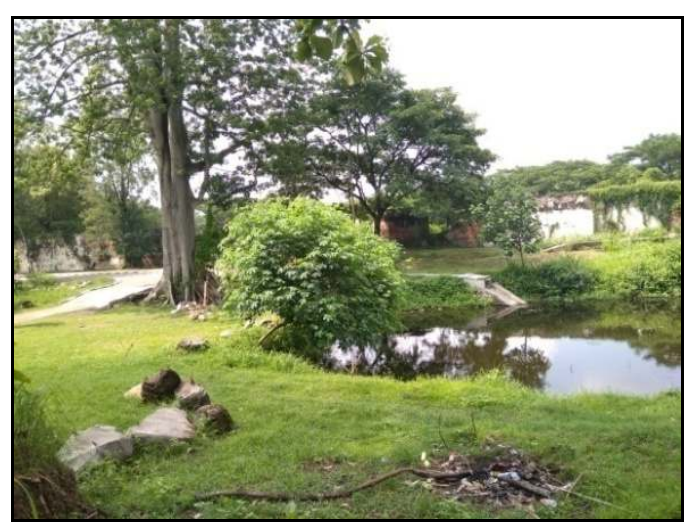

Figure 2. A trench that does not already function again 


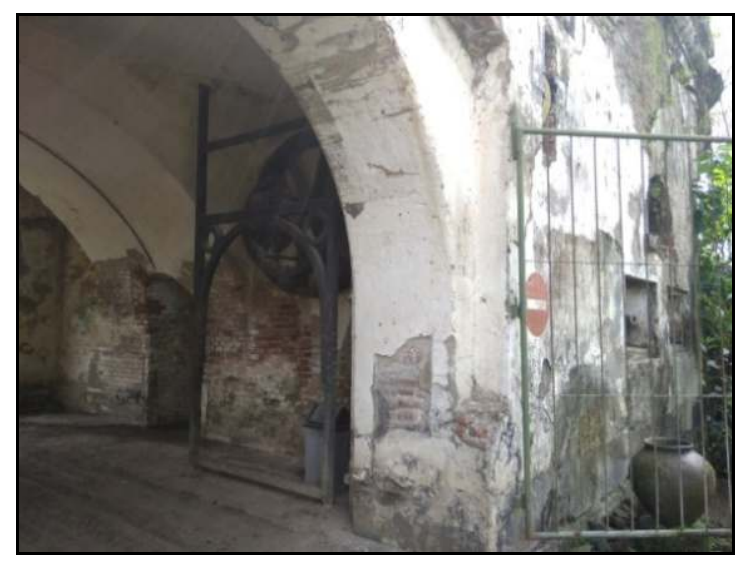

Figure 3. A lift bridge that is no longer visible and only separates the pulley to pull the bridge

The building materials used in Van Den Bosch Fort are brick and teak wood which is easily found in Ngawi Regency. The method used to glue bricks to each other using a mixture of red cement, lime, and sand (Figure 4-5).

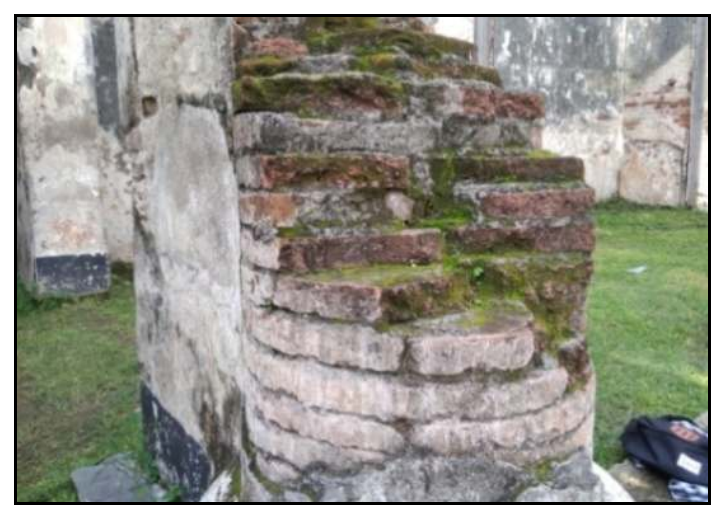

Figure 4. A material of the walls of the fortress of Van Den Bosch uses red brick

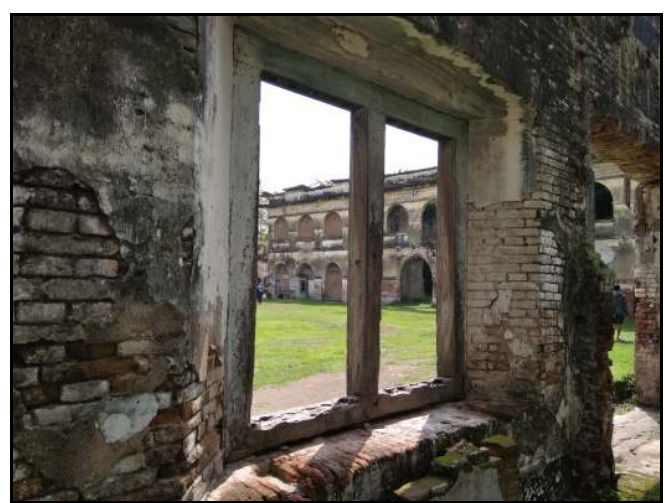

Figure 5. The fort frame uses teak wood

In mid-2017 Regional Government of Ngawi Regency through the District Head of Ngawi Regency, Ir. H. Budi Sulistyono mandated the Yogyakarta Special Archeology Center to conduct phase III research related to the architecture, functions and historical context of Van Den Bosch Fortress.

In this study, it was found that most of the buildings in the fortress continued to experience deterioration in quality, as evidenced by the existence of several buildings which only separated the skeleton, related to these findings. by strengthening the structure or returning it to be rebuilt as originally set up, so that it requires thorough study and may also have an impact on the master plan that has been prepared in advance so the master plan needs to be reviewed. 


\subsection{Ownership}

Regarding the ownership status of the Van Den Bosch Fort area, this fort is owned by the Infantry Dua Kostrad Division. The Regional Government of Ngawi Regency has collaborated on the use of land and building assets of the Fort Van Den Bosch area with the MoU. So far, the existence of the Van Den Bosch fortress is indeed under the ownership of the Ministry of Finance (Ministry of Finance) while the Division Two Kostrad Infantry position is limited to asset users so that the revitalization of Fort Van Den Bosch is still limited by the Cooperation Agreement (PKS) as an administrative requirement so that revitalization was delayed and not on schedule.

\subsection{Planning}

Recently the fortress of Van Den Bosch is undergoing revitalization. This revitalization activity is carried out by the Dinas Pekerjaan Umum (PU), revitalization activities are carried out divided into three stages (Table 1).

Table 1. Stages in revitalizing the Van Den Bosch Fort Area.

\begin{tabular}{|c|c|c|c|c|}
\hline No & Stages & Activities & Sub Activity & Implementation \\
\hline \multirow[t]{3}{*}{1} & \multirow[t]{3}{*}{$\begin{array}{l}\text { First } \\
\text { stage }\end{array}$} & \multirow[t]{3}{*}{$\begin{array}{l}\text { Revitalizing the core } \\
\text { area of Van Den } \\
\text { Bosch Fortress }\end{array}$} & $\begin{array}{l}\text { Land clearing is the initial stage } \\
\text { and is preparation before the } \\
\text { process of revitalizing the core } \\
\text { building of the fort }\end{array}$ & Implemented \\
\hline & & & $\begin{array}{l}\text { Trench excavation to restore the } \\
\text { shape and function of the trench } \\
\text { that surrounds Van Den Bosch } \\
\text { Fort }\end{array}$ & Not yet done \\
\hline & & & $\begin{array}{l}\text { The making of pedestrians and } \\
\text { parks aims to develop pedestrian } \\
\text { lanes that surround the Riverside }\end{array}$ & Not yet done \\
\hline \multirow[t]{3}{*}{2} & \multirow[t]{3}{*}{$\begin{array}{l}\text { Second } \\
\text { stage }\end{array}$} & \multirow[t]{3}{*}{$\begin{array}{l}\text { Development } \\
\text { activities of the fort } \\
\text { area }\end{array}$} & $\begin{array}{l}\text { The development of the entrance } \\
\text { area consists of a gate area, } \\
\text { pedestrian and guard post }\end{array}$ & Implemented \\
\hline & & & $\begin{array}{l}\text { Revitalization of fortress phase } \\
1 \text { consists of land clearing, ditch } \\
\text { repair, and fortress conservation }\end{array}$ & Not yet done \\
\hline & & & $\begin{array}{l}\text { Development of supporting } \\
\text { facilities, in the form of parks, } \\
\text { gazebos, toilets, parking lots, } \\
\text { kiosks, and friendship networks }\end{array}$ & $\begin{array}{l}\text { Implemented: } \\
\text { There is no kiosk }\end{array}$ \\
\hline \multirow[t]{2}{*}{3} & \multirow[t]{2}{*}{$\begin{array}{l}\text { Third } \\
\text { stage }\end{array}$} & \multirow{2}{*}{$\begin{array}{l}\text { Continue the } \\
\text { development of the } \\
\text { fort area } \\
\text { environment. }\end{array}$} & $\begin{array}{l}\text { Addition of supporting facilities, } \\
\text { such as souvenir kiosks, toilets, } \\
\text { gazebos, and utility networks }\end{array}$ & $\begin{array}{l}\text { Implemented: } \\
\text { There is no kiosk }\end{array}$ \\
\hline & & & $\begin{array}{l}\text { Additional tourist attractions } \\
\text { consisting of the science park, }\end{array}$ & Not yet done \\
\hline
\end{tabular}




\section{culinary center, and viewing \\ tower}

The arrangement of pedestrian Not yet done
lanes

Revitalization of fortress stage 2 Not yet done

From the explanation in table 1 , it can be seen that the stages in revitalizing the fort area still have many activities that have not yet been carried out and the revitalization process carried out in the fort is more focused on developing the fort area environment which aims to repair and revive the image of the Fort Van Den Bosch Fortress (Figure 6-8).

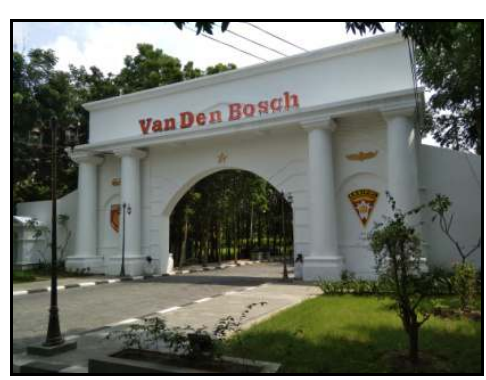

Figure 6. Development of the entrance area of the Van Den Bosch fort area

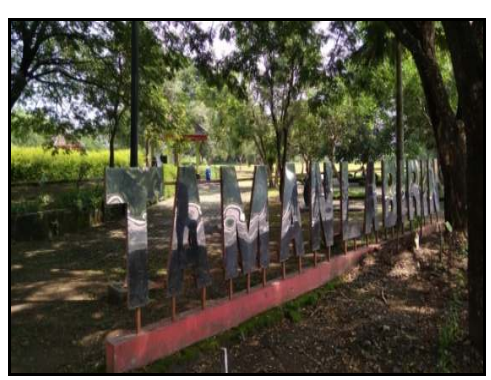

Figure 7. Development of supporting facilities such as parks and gazebos

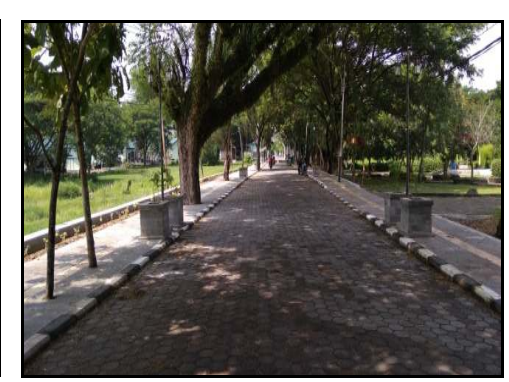

Figure 8. Development of supporting facilities: pedestrian and main access road to the fort

\subsection{Economy}

With the opening of Fort Van Den Bosch to the public in 2012 and experiencing some environmental development in the fort area and with the construction of several supporting facilities, many people around the fort were employed as ticket officer managers and janitors. There were also people around the fort who used the opening of the fort, in general, to open food and drink places inside the fort area. However, it has not yet had a widespread impact on the economic development of the communities around the fort (Figure 9).

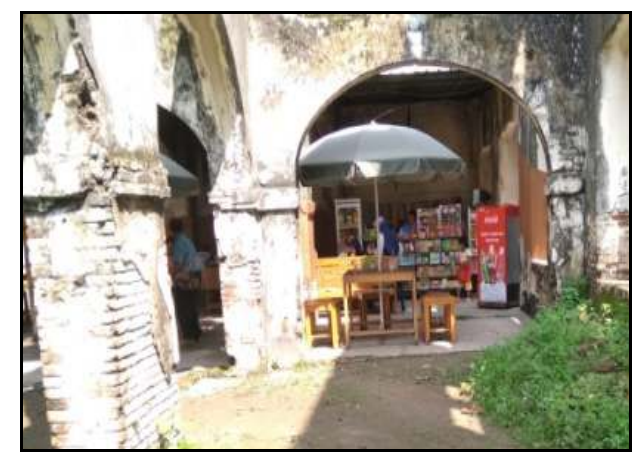


Figure 9. People around Fort Van Den Bosch

who opened a place to eat and drink inside the fort building

\subsection{Social Activity}

The opening of Van Den Bosch Fortress for the public can be used as an object to learn about history. This can be seen when the measurement and data collection of the fort is carried out by PU Ngawi, involving several students from schools from the city of Ngawi, besides being involved in measuring and collecting fortifications, students were also informed about how to maintain and utilize the Van Den Bosch Fortress to maintain its existence (Figure 10).

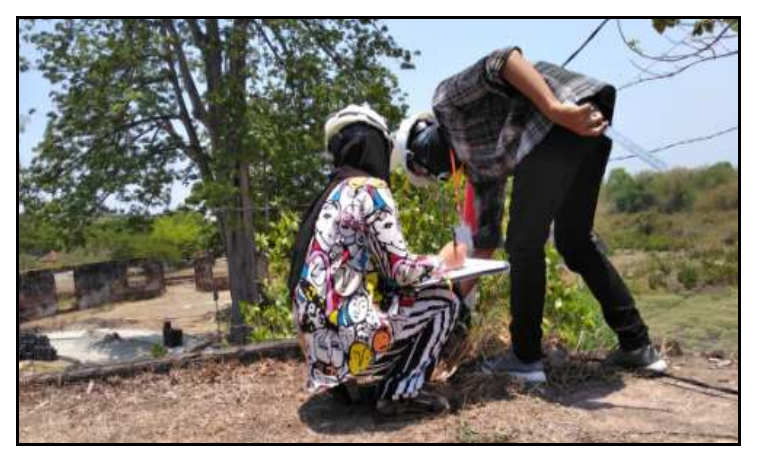

Figure 10. Activities of SMK PGRI 1 students Ngawi in measuring and data collection of Van Den Bosch Fort

\section{Conclusions, Recommendations, And Acknowledgments}

From the results and discussions conducted in the sub-section above, it can be concluded that the revitalization of the Van Den Bosch fort area is as follows:

The implementation of the revitalization program in the Benteng Van Den Bosch area is limited by the Collaborative Agreement (PKS) as one of the administrative requirements that causes revitalization to be delayed and not in accordance with the schedule, which then affects the revitalization of Benten Van Den Bosch carried out by Dinas Pekerjaan Umum Kabupaten Ngawi, so there are still many activities that have not been carried out.

The revitalization of the Benteng Van Den Bosch area is divided into 2 types, namely the revitalization of the core building of the fort and the development of the fort area environment.

The revitalization of the core building of the fortress of Van Den Bosch has just reached the stage of cleaning and preparation to date because of Pemerintah Daerah Kabupaten Ngawi still reviewing recommendations that are good for the fort are maintained as they are now but by strengthening the structure or returning to the initial form. The revitalization that has been done lately is more at the development stage of the development of the Van Den Bosch fort by building facilities such as gates, pedestrians, parks, gazebos, guard posts, and toilets that aim to 
revive the area and improve the image quality of the Van Den Bosch fortress. So far the development of supporting facilities in the fort area has not yet clung to the economic development of the community around Van Den Bosch Fort. Fort Van Den Bosch is used for historical learning objects by involving several students in measuring and documenting and students are also taught how to maintain and care for the fort. Based on the results of the research carried out and through several steps taken, the recommendations that can be given by the author regarding the implementation of the revitalization program at the Van Den Bosch fort are as follows: The government needs to immediately determine further action to decide which action is more appropriate for the core construction of the Van Den Bosch fort, which is maintained as it is today, but by strengthening its structure or returning it to be rebuilt as originally formed so that objects remain safe and can be utilized. When viewed from the point of view of building materials, the fortress of Van Den Bosch is dominated by red bricks and teak wood, so that at the revitalization stage the core buildings that have been damaged and require new materials can use the same material because in Ngawi Bahan Regency is easy to find.

In revitalizing the Van Den Bosch Fortress, it will run well if it involves all parties. Starting from the government, the private sector and the community. So that in the future it is hoped that the revitalization of the fort can run optimally, indirectly the community will also take care of and protect the buildings of the Fort Van Den Bosch and also have an impact on improving the economy of the communities around the fort.

\section{Acknowledgments}

Thank you to the Master of Architecture Program, Indonesian Islamic University who has provided opportunities and direction to the author in the research conducted.

\section{References}

[1] Kabupaten Ngawi, Peraturan Daerah Kabupaten Ngawi Nomor 10 Tahun 2013 Tentang Pelestarian, Pengembangan Cagar Budaya dan Seni Budaya Tradisional. 2013.

[2] M. Chawari, "Wawancara 'Revitalisasi Benteng Van Den Bosch' di Balai Arkeologi Yogyakarta.," 2018.

[3] M. Chawari, "Laporan Penelitian Arkeologi Penelitian Benteng Van den Bosch di Kabupaten Ngawi, Provinsi Jawa Timur,” Balai Arkeologi Yogyakarta, 2014.

[4] M. Chawari, "Laporan Penelitian Arkeologi Arsitektur, Fungsi, Dan Konteks Sejarah Benteng Van Den Bosch, Ngawi, Jawa Timur," Balai Arkeologi Yogyakarta, 2017.

[5] J. A. Widayat, "Revitalisasi Benteng Van Den Bosch Ngawi Dengan Pendekatan Adaptive Reuse Dan Konsep Infill Design," Universitas Muhammadiyah Surakarta, 2018.

[6] Kementerian Pekerjaan Umum dan Perumahan Rakyat, "Program Penataan dan Pelestarian Kota Pusaka (P3KP)," 2012. [Online]. Available: http://sim.ciptakarya.pu.go.id/kotapusaka/page/3-program-penataan-dan pelestarian- 
kota-pusaka-p3kp.

[7] \& S. Solikhah, A., Setijanti, P., "Studi Perkembangan Dan Konsep Revitalisasi Tata Lingkungan Tradisional Baluwarti Surakarta," 2012.

[8] B. Carter, "harter for the Conservation of Place of Cultural Significance," 1981. [Online]. Available: http://australia.icomos.org/wp-content/uploads/burra carter.pdf.

[9] W. Danisworo, Muhammad Martokusumo, "Revitalisasi Kawasan Kota Sebuah Catatan dalam Pengembangan dan Pemanfaatan Kawasan Kota," 2000.

[10] M. B. dan A. M. H. Miles, "Analisis Data Kualitatif, Buku sumber tentang metodemetode baru," 2007. 